\title{
Description and Assessment of a Small Renewable Energy Community in the Island of Crete, Greece
}

\author{
John Vourdoubas \\ Department of Natural Resources and Environmental Engineering, Technological Educational Institute of Crete, \\ Crete, Greece \\ Email: vourdoubas@chania.teicrete.gr
}

How to cite this paper: Vourdoubas, J. (2017) Description and Assessment of a Small Renewable Energy Community in the Island of Crete, Greece. Open Journal of Energy Efficiency, 6, 97-111. https://doi.org/10.4236/ojee.2017.63008

Received: August 15, 2017

Accepted: September 4, 2017

Published: September 7, 2017

Copyright (C) 2017 by author and Scientific Research Publishing Inc. This work is licensed under the Creative Commons Attribution International License (CC BY 4.0).

http://creativecommons.org/licenses/by/4.0/ cc) (i) Open Access

\begin{abstract}
A description and assessment of a small renewable energy community located in Crete, Greece is presented. The community included private residential and agricultural activities without any involvement of the public sector. Small-scale decentralized energy systems were used. Solar energy and solid biomass which are locally available covered most of the heat and electricity requirements in the community. Renewable energy technologies used include solar thermal energy, solar-PV and solid biomass burning utilizing olive tree wood and olive kernel wood. These technologies are mature, reliable, well proven in Crete and cost-effective. Existing energy systems were generating 857,877 kWh per year covering $94.46 \%$ of the current energy requirements in the community, significantly reducing its emissions at $278,494 \mathrm{~kg} \mathrm{CO}_{2}$ per year. The addition of a new solar-PV system with nominal power of $33.6 \mathrm{kWp}$ could cover all the remaining electricity needs in the community, transforming it to a zero- $\mathrm{CO}_{2}$ emission community due to energy use. The total installation cost of the existing renewable energy systems in the community was estimated at $0.16 €$ per total $\mathrm{kWh}$ of thermal and electric energy generated annually and at $0.50 €$ per ton of $\mathrm{CO}_{2}$ emissions saved annually. Results indicated that the creation of the above-mentioned small local energy community is economically viable, environmental friendly and socially accepted. Therefore it could be replicated in other territories with similar availability of renewable energies, increasing their energy autonomy and sustainability.
\end{abstract}

\section{Keywords}

$\mathrm{CO}_{2}$ Emissions, Crete-Greece, Renewable Energy, Solar Energy, Sustainable Energy Communities 


\section{Introduction}

The necessity to mitigate greenhouse gas emissions and to decrease the use of fossil fuels has increased the efforts for utilizing renewable energy (RE) sources, wherever possible. Designing and implementing decentralized RE projects in local societies following the bottom-up approach results in many environmental, energy, social and economic benefits, promoting the target of sustainability in various territories. Recently the idea of local RE communities is supported and promoted in EU countries with various national and regional incentives.

\subsection{Renewable Energy Communities}

Guidelines for a sustainable energy community (SEC) have been published [1]. According to those guidelines a SEC is one in which everyone works together to develop a sustainable energy system. To do so, they aim as far as possible to be energy efficient, to use RE where feasible and to develop decentralized energy supplies. A viewpoint on community RE has been published by Walker et al., 2008 [2]. The authors investigated the differences between community RE projects and other RE installations. They considered the answer in two questions: who the project is by (process), and who the project is for (outcome), in order to identify the involvement of the local community in the project development and to categorize the project as community RE. Energy autonomy in SECs has been reported by Rae et al., 2012 [3]. The authors stated that generation and utilization of renewable energies have technical, economic and environmental challenges. However their social and political impacts should also be taken into account. Successful existing projects in islands and remote communities provide a useful indication of the challenges and opportunities which are likely to arise in future projects. Lessons from Australia regarding the transition to low-carbon communities have been reported by Moloney et al., 2010 [4]. The authors stated that many community-based programs have adopted an integrated approach, focusing on both technical and behavioral dimensions in the shift to low-carbon communities. They concluded that behavioral changes in order to decrease consumption are an important factor towards the transition to low-carbon communities. Key elements of a RE community have been presented by Carlisle et al., 2008 [5]. The authors outlined five elements needed to create a RE community, which are:

1) Sustainable design approach,

2) Solar/zero-energy buildings and/or micro-grids,

3) Advanced and energy-efficient transportation,

4) Utility role expansion, power generation and load management, and

5) Putting it all together for a RE community

They reported that supplying adequate clean energy to a rapidly industrialized world is one of the $21^{\text {st }}$ century's greatest challenges. Designing new communities using a RE systems approach could significantly decrease the use of fossil fuels and the emissions of greenhouse gases. A report on social acceptance of RE 
innovation has been published by Wustenhagen et al., 2007 [6]. The authors stated that social acceptance is an important factor which could constrain the development of RE projects. This is particularly apparent in the case of wind energy, largely due to its visual impacts on landscapes. The public perceptions for community-based RE projects have been reported by Rogers et al., 2008 [7]. The authors stated that community-based RE projects are more likely to be accepted by the public than top-down development of large-scale schemes. According to their investigations using questionnaires, the local community responded positively in the development of community-based RE projects. However the local inhabitants were not keen on developing and leading such a project. A report on sustainable energy communities (SEC) framework has been published, in 2016, [8]. It is stated that the creation of a SEC requires local knowledge, involvement of local citizens and time spent. Sustainable energy authority of Ireland can provide skills development, funding and technical support in order to design and implement a local RE project. The authors also stated that there are 28 members in the sustainable energy authority network in Ireland. An assessment of the impact of RE deployment on local sustainability has been presented by Rio et al., 2008 [9]. The authors stated that deployment of renewable energies has many positive impacts in local communities. Apart from the environmental benefits, socioeconomic benefits are also important. These include diversification of energy supply, enhanced regional and rural development opportunities, creation of a domestic industry and employment opportunities. Community innovation for sustainable energy has been reported by Hielscher et al., 2011 [10]. The authors stated that community-based initiatives are developing new energy-related consumption practices with a view to the socio-technical transition to local, renewable or lower carbon systems. They concluded that community energy approaches are multi-faceted and they are interested in achieving sustainability. Configurations between "the public" and RE have been reported by Walker et al., 2007 [11]. The authors, with reference to the deployment of renewable energies in the UK, outlined five different modes of cooperation between technology and social organization. The five modes of implementation of RE projects in the UK include: public utility, private supplier, community, household and business. Community RE projects' ownership includes various types of partnerships, cooperatives and user-led initiatives. The barriers and incentives for community-owned means of energy production and use have been reported by Walker, 2008 [12]. The author stated that incentives for community-led energy projects include: Creation of local income, local approval and planning permission, local control, lower energy costs and reliable supply, ethical and environmental commitment and load management. Barriers to those projects include unclear legal conditions under which the projects will operate, uncertain economic and technical viability, need for extensive liaison and expert advice. The author concluded that in other EU countries, like Denmark and Austria, there is a far more significant level of community ownership regarding 
RE projects than in UK.

\subsection{Solar Photovoltaic Electricity}

An economic analysis of different supporting policies for the production of electrical energy by solar-PVs in European Union countries has been reported by Dusonchet et al., 2010 [13]. The authors stated that according to their analysis in many cases the differences between the implementation of the same support policy in different countries can give rise to significantly different results. A review on photovoltaic self-consumption in buildings has been reported by $\mathrm{Lu}$ thander et al., 2015 [14]. The authors examined two options for increased self-consumption. The first included PV-battery systems with battery storage capacity of $0.1-1 \mathrm{kWh}$ per installed $\mathrm{kWp}$ and the second demand-side management (DSM). They stated that with a battery storage system the relative self-consumption could be increased by $13 \%-24 \%$ and with DSM by $2 \%-15 \%$. An energy and economic evaluation of building-integrated photovoltaics (BIPVs) has been presented by Oliver et al., 2001 [15]. The authors stated that BIPVs offer cost reductions in both energy and economic terms over centralized PV plants. They concluded that BIPVs offer the "double dividend" of reduced economic costs and improved environmental performance. A holistic approach of BIPVs in the UK has been presented by Hammond et al., 2012 [16]. The authors implemented an energy analysis, an environmental analysis and an economic appraisal. Their findings indicated that the PV system generating electricity paid back its embodied energy in 4.5 years. The economic analysis indicated that it is unlikely to pay back its investment over the 25-year lifetime. Vourdoubas, 2016 [17] has reported on the possibility of creating zero- $\mathrm{CO}_{2}$ emissions residential buildings due to energy use with reference to the island of Crete, Greece. The author stated that with the use of locally available renewable energies all the energy requirements of the residential buildings could be covered. He indicated two different combinations of renewable energy technologies (RET) which could achieve this goal. The first included solar thermal energy, solar-PV and solid biomass and the second solar thermal energy, solar-PV and high efficiency heat pumps. Tselepis, 2015 [18] has reported on the PV market developments in Greece regarding net-metering. Implementing case studies for PV installations in a household and a commercial enterprise, he indicated that these investments are currently attractive.

\subsection{Solar Thermal Energy for Hot Water Production}

Solar thermal markets (STMs) in Europe have been presented by the European Solar Thermal Industry Federation, 2015 [19]. According to this report total solar thermal capacity in Europe has reached $31.8 \mathrm{GW}$ th and the single-family housing still represents the bulk of the STMs. Greek STMs are some of the most important in Europe and current development is mainly due to the growing tourism sector. Total installed capacity in the country has reached $3 \mathrm{GWth}$. Solar 
heating and cooling for a sustainable energy future in Europe has been reported by the European Solar Thermal Technology Platform [20], who claim that solar thermal technology has the potential to cover $50 \%$ of the total EU heat demand which corresponds to $49 \%$ of the total energy demand in Europe. The required technologies are available or can be developed to cover most of this demand. Solar thermal applications are based on solar energy which is available everywhere and its use for domestic hot water production is popular in various countries. Solar thermal heating for residential applications has been reported by the IEA and IRENA Technology Brief, 2015 [21]. According to this report solar domestic water heating technology has become a common application in many countries. Solar thermal systems are mainly manufactured by local small- and medium-size enterprises which also install and maintain them.

\subsection{Solid Biomass Burning for Space Heating}

An overview of RE applications in Crete has been reported by Zografakis, 2005

[22]. The author stated that thermal uses of solid biomass in Crete, including applications in olive oil mills, bakeries, greenhouses, hotels and dwellings, contribute $8.5 \%$ of the total energy consumption in the island. Investigation of non-technical barriers which might prevent biomass use for energy generation has been presented by Rosch et al., 1999 [23]. The authors stated that apart from the technical problems related with biomass use for energy generation, there are various non-technical problems related with funding, insurance, administrative regulations, organizational complexity and public acceptance which hinder in many cases the promotion of biomass-to-energy projects. An overview of the biomass resource potential for energy generation in Norway has been presented by Scarlat et al., 2011 [24]. The authors stated that although the contribution of RE in Norway is among the highest in Europe, due to hydroelectricity, biomass has a low contribution to the Norwegian energy supply. They suggested that Norway should benefit from the experience gained in Denmark, Sweden and Finland regarding bio-energy use. Vourdoubas, 2015 [25] has reported on a greenhouse used for flower cultivation in Crete, which was heated with olive kernel wood, locally produced in Crete. Olive kernel wood, a by-product of the olive oil producing industry, is a cheap, renewable fuel extensively used for heat generation in the island. All the annual heating needs of the greenhouse, corresponding to $95.31 \%$ of its total energy needs, were covered with this biomass source.

The aim of the current work is to describe and assess a small RE community located on the island of Crete, Greece. Various RET used in buildings and other local activities are described together with an estimation of heat and electricity production and consumption. An economic and environmental assessment of the RE community combined with its main characteristics is also presented. The results of this study indicated that the creation of sustainable energy communities utilizing locally available RE and reliable, cost-effective technologies has many economic, social and environmental advantages. 


\section{Renewable Energy Community}

\subsection{Description of the Small Energy Community in Crete}

Renewable energy systems providing heat and electricity have been installed in various small, grid-connected, residential flats and two small greenhouses used for flower cultivation. The buildings and the greenhouses, privately owned, are located in a rural area in the municipality of Platanias, in Western Crete. The aim of this small energy community was to cover nearly all of its energy needs with locally available renewable energies, including solar energy and solid biomass, minimizing the use of fossil fuels. The owners of the residential flats and greenhouses were committed to this aim. The replacement of conventional fuels with renewable energies would result in a significant decrease of $\mathrm{CO}_{2}$ emissions due to energy use in the community. There are fifteen (15) residential flats in the community with a total covered surface of $795 \mathrm{~m}^{2}$. The covered area of the two (2) small greenhouses was 0.33 ha. Energy demand in the residential flats included energy use for space heating and cooling, lighting, hot water production and for the operation of various electric appliances. Energy demand in the greenhouses included energy use for space heating and cooling, lighting and the operation of various electric equipment and machinery. Local climate in mild and average monthly air temperatures in Chania vary between $10.8^{\circ} \mathrm{C}$ and $15.8^{\circ} \mathrm{C}$. Energy demand in a typical residential building of this type in Crete is presented in Table 1. Energy demand has been estimated in each sector by dividing the total energy demand by a percentage which is representative for Greek residential buildings according to various studies.

The total annual energy requirements in the fifteen (15) residential flats was $135,150 \mathrm{kWh}$ and their distribution in various sectors is presented in Table 2.

Table 1. Energy demand in a typical residential building in Crete.

\begin{tabular}{ccc}
\hline Sector & Energy use $\left(\mathrm{kWh} / \mathrm{m}^{2}\right.$ year $)$ & $\%$ \\
\hline Space heating & 107.1 & 63 \\
Hot water production & 15.3 & 9 \\
Lighting & 20.4 & 12 \\
Operation of various appliances including space cooling & 27.2 & 16 \\
Total & 170 & 100 \\
\hline
\end{tabular}

Source: Vourdoubas, 2016

Table 2. Annual energy requirements in the 15 residential flats in the community.

\begin{tabular}{cc}
\hline Sector & Annual energy needs $(\mathrm{kWh})$ \\
\hline Space heating & 85,145 \\
Hot water production & 12,163 \\
Total heating energy & 97,308 \\
Lighting & 16,218 \\
Operation of various appliances including space cooling & 21,624 \\
Total electricity & 37,842 \\
Total & 135,150 \\
\hline
\end{tabular}


Annual energy demand in the two greenhouses (Vourdoubas, 2016) was as follows:

1) For space heating, $724,569 \mathrm{kWh}$ corresponding to $95.31 \%$ of the total energy needs, and

2) For electricity, $48,500 \mathrm{kWh}$, corresponding to $4.69 \%$ of the total energy needs, with total energy requirements at $773,069 \mathrm{kWh}$.

Annual energy requirements per sector in both the residential flats and greenhouses are presented in Table 3.

Data from Table 3 indicated that:

1) The ratio of heat to electricity consumption was higher in the greenhouses than in residential buildings,

2) Heat consumed for hot water production was only a small fraction of the total heat requirements, and

3) Heat requirements were slightly higher than $90 \%$ of total energy requirements in buildings and greenhouses while the rest accounted for electricity.

\subsection{Technologies Used}

Emphasis on the above-mentioned sustainable energy community has been given in the use of decentralized energy supply utilizing locally available RE. The RE systems used, except for the PV panels, have been manufactured and installed by local companies. The local University contributed in the estimation of their capacity and their specifications. These systems were mature, reliable, well-proven and cost-effective. The existing legal framework in Greece allows their use for heat and electricity generation.

\subsubsection{Solar Thermal Energy for Hot Water Production}

Solar energy was used for hot water production in the buildings. Individual solar

Table 3. Annual energy requirements per sector both in residential buildings and in the greenhouses $(\mathrm{kWh})$.

\begin{tabular}{|c|c|c|c|c|c|c|}
\hline & $\begin{array}{l}\text { Residential } \\
\text { flats }\end{array}$ & $\%$ & Greenhouses & $\%$ & Total & $\begin{array}{l}\% \text { of } \\
\text { total }\end{array}$ \\
\hline Space heating & 85,145 & 63.00 & 724,569 & 95.31 & 809,682 & 89.16 \\
\hline Hot water & 12,163 & 9.00 & 0 & & 12,163 & 1.33 \\
\hline $\begin{array}{c}\text { Total heating } \\
\text { energy }\end{array}$ & 97,308 & 72.00 & 724,569 & 95.31 & 821,845 & 90.49 \\
\hline Lighting & 16,218 & 12.00 & & & & \\
\hline $\begin{array}{l}\text { Operation of } \\
\text { appliances and } \\
\text { equipment } \\
\text { including } \\
\text { space cooling }\end{array}$ & 21,624 & 16.00 & & & & \\
\hline $\begin{array}{c}\text { Total } \\
\text { electricity }\end{array}$ & 37,842 & 28.00 & 48,500 & 4.69 & 86,342 & 9.51 \\
\hline Total energy & 135,150 & 100.00 & 773,069 & 100.00 & 908,173 & 100.00 \\
\hline
\end{tabular}


thermo-siphonic systems were used in each flat with a flat-plate collector surface of $2 \mathrm{~m}^{2}$ and a water tank volume of $160 \mathrm{lt}$. The total area of the flat-plate collectors was $30 \mathrm{~m}^{2}$ and their total thermal power $21 \mathrm{kWth}$. Solar thermal systems used were expected to cover approx. $80 \%$ of the annual requirements in hot water in the flats while the rest was covered with electricity. The solar thermal systems were placed on the roof terrace of the buildings.

\subsubsection{Solar Photovoltaic Systems}

Solar photovoltaic systems were used for electricity generation located also on the roof terrace of the buildings. The electricity generated was injected into the grid according to the net-metering initiative. Five small PV systems were installed in five buildings. The total installed capacity of the photovoltaic systems was $24 \mathrm{kWp}$ and the estimated annual electricity generation 36,000 kWh. Installation of PVs in the greenhouses has not been currently implemented, but it is foreseen for the near future.

\subsubsection{Solid Biomass Burning Systems Used in the Buildings}

A wood stove was installed in each flat for space heating. Locally produced olive tree wood was the main biomass source used in the stoves providing all the required heat. The power of the wood stoves varied between 12 to $20 \mathrm{kWth}$ depending on the size of each flat, and their thermal efficiencies varied at 50\% $60 \%$.

\subsubsection{Solid Biomass Burning System Used in the Greenhouse}

Space heating in the greenhouse was obtained with a heating system using olive kernel wood, a by-product of the olive oil producing industry in Crete. The thermal power of the biomass burning system was $750 \mathrm{kWth}$ with an efficiency of approx. $70 \%$. The heating value of the olive kernel wood was approximately $4200 \mathrm{Kcal} / \mathrm{kg}$ (at 10\% moisture content) and the heating system covered all the annual heating needs in the greenhouse. The characteristics of the systems used for energy generation in the community are presented in Table 4.

Data from Table 4 indicated that energy generation in the energy community from solid biomass $(832,569 \mathrm{kWh})$ accounts for more than $90 \%$ of total energy generation $(923,319 \mathrm{kWh})$.

\subsection{Key Features of the Small Renewable Energy Community}

The key features of the above-mentioned sustainable energy community are as follows:

1) It includes a mix of sectors including the residential and the agricultural sector,

2) It is located in a defined geographical area in the municipality of Platanias, in Western Crete,

3) It enjoys a strong stakeholders' commitment,

4) Stakeholders are only private bodies,

5) It has a defined management structure, 
Table 4. Characteristics of the systems used for energy generation in the community.

\begin{tabular}{|c|c|c|c|c|c|c|}
\hline $\begin{array}{l}\text { Energy } \\
\text { system }\end{array}$ & $\begin{array}{c}\text { Energy } \\
\text { generated }\end{array}$ & Power & $\begin{array}{c}\text { Energy } \\
\text { generation } \\
(\mathrm{kWh})\end{array}$ & $\begin{array}{l}\% \text { of } \\
\text { total }\end{array}$ & $\begin{array}{c}\text { Energy/Fuel } \\
\text { used }\end{array}$ & $\begin{array}{c}\text { Quantity } \\
\text { of fuel } \\
\text { used }\end{array}$ \\
\hline $\begin{array}{l}\text { Solar } \\
\text { thermal }\end{array}$ & Heat & $21 \mathrm{kWth}$ & 54,750 & 5.93 & Solar energy & 0 \\
\hline Solar-PV & Electricity & 24 kWp & 36,000 & 3.90 & Solar energy & 0 \\
\hline $\begin{array}{l}\text { Biomass } \\
\text { burning } \\
\text { system in the } \\
\text { buildings }\end{array}$ & Heat & $\begin{array}{c}240 \\
\mathrm{~kW} \text { th }\end{array}$ & 108,000 & 11.70 & $\begin{array}{l}\text { Olive tree } \\
\text { wood }\end{array}$ & $\begin{array}{c}35.22 \\
\text { tons/year }\end{array}$ \\
\hline $\begin{array}{l}\text { Biomass } \\
\text { burning } \\
\text { system in the } \\
\text { greenhouse }\end{array}$ & Heat & $\begin{array}{c}750 \\
\text { kWth }\end{array}$ & 724,569 & 78.47 & $\begin{array}{c}\text { Olive kernel } \\
\text { wood }\end{array}$ & $\begin{array}{c}200 \\
\text { ton/year }\end{array}$ \\
\hline Total & & $\begin{array}{c}24 \mathrm{kWp} \\
\text { electric } \\
\text { and } \\
1011 \\
\text { kWth } \\
\text { thermal }\end{array}$ & 923,319 & 100.00 & & $\begin{array}{c}235.22 \\
\text { tons/year }\end{array}$ \\
\hline
\end{tabular}

6) Targets, including zeroing of $\mathrm{CO}_{2}$ emissions due to energy use, are more ambitious than the national targets,

7) The community produces clear and recognizable benefits and results.

\section{Assessment of the Renewable Energy Community}

\subsection{Energy Assessment}

Energy generation in the sustainable community should cover the majority of its heat and electricity requirements. Energy supply and demand in the buildings and greenhouses as well as the energy surplus or deficit are all presented in $\mathrm{Ta}$ ble 5 .

Heat generated by solid biomass exceeds the heat requirements in the buildings and it covers all the heat requirements in the greenhouses. However electricity annually generated by PVs installed in the buildings is slightly less than their requirements while in the greenhouses there is no PV installation. In order to cover all the additional electricity requirements in both the buildings and greenhouses, which have been estimated at $50,342 \mathrm{kWh}$, additional installation of photovoltaics is needed. The nominal power of the additional PVs is 33.6 $\mathrm{kWp}$, (assuming that the annual electricity generation in Crete from PVs is 1500 $\mathrm{kWh}$ per kWp).

\subsection{Economic Assessment}

The installation cost of the RE systems used in the energy community has been estimated in Table 6.

According to Table 6 the cost of the RE systems used in the greenhouses was 
Table 5. Energy demand and supply in the buildings and greenhouses.

\begin{tabular}{cccc}
\hline Sector & $\begin{array}{c}\text { Energy demand } \\
(\mathrm{kWh})\end{array}$ & $\begin{array}{c}\text { Energy supply } \\
(\mathrm{kWh})\end{array}$ & $\begin{array}{c}\text { Surplus/Deficit } \\
(\mathrm{kWh})\end{array}$ \\
\hline $\begin{array}{c}\text { Space heating in the } \\
\text { buildings }\end{array}$ & 85,145 & 108,000 & $+22,855$ \\
$\begin{array}{c}\text { Hot water in the } \\
\text { buildings }\end{array}$ & 12,163 & 54,750 & $+42,587$ \\
$\begin{array}{c}\text { Electricity in the } \\
\text { buildings }\end{array}$ & 37,842 & 36,000 & -1842 \\
$\begin{array}{c}\text { Space heating in the } \\
\text { greenhouses }\end{array}$ & 724,569 & 724,569 & 0 \\
$\begin{array}{c}\text { Electricity in the } \\
\text { greenhouses }\end{array}$ & 48,500 & 0 & $-48,500$ \\
Total heat & 821,877 & 887,319 & $+66,442$ \\
$\begin{array}{c}\text { Total electricity } \\
\text { Total heat and } \\
\text { electricity }\end{array}$ & 86,342 & 36,000 & $-50,342$ \\
\hline
\end{tabular}

Table 6. Installation cost of the RE systems used in the energy community.

\begin{tabular}{|c|c|c|c|}
\hline Renewable energy system & $\begin{array}{l}\text { Nominal power } \\
(\mathrm{kWp} \text { or } \mathrm{kWth})\end{array}$ & $\begin{array}{l}\text { Unit cost } \\
(€ / \mathrm{kW})\end{array}$ & Installation cost $(€)$ \\
\hline Solar thermal system & 21 & 600 & 12,600 \\
\hline Solar-PV & 24 & 1700 & 40,800 \\
\hline $\begin{array}{l}\text { Solid biomass burning systems } \\
\text { in the buildings }\end{array}$ & 240 & 40 & 9600 \\
\hline $\begin{array}{l}\text { Solid biomass burning systems } \\
\text { in the greenhouses }\end{array}$ & 750 & 100 & 75,000 \\
\hline $\begin{array}{l}\text { Additional PV system to cover all } \\
\text { the electricity requirements in the } \\
\text { community }\end{array}$ & 33.6 & 1700 & 57,120 \\
\hline $\begin{array}{l}\text { Total cost of photovoltaics including } \\
\text { the additional required PV }\end{array}$ & & & 97,920 \\
\hline $\begin{array}{l}\text { Total cost of biomass } \\
\text { burning systems }\end{array}$ & & & 84,600 \\
\hline $\begin{array}{l}\text { Total cost of RE systems } \\
\text { used in the buildings }\end{array}$ & & & 63,000 \\
\hline $\begin{array}{l}\text { Total cost of RE systems } \\
\text { used in the greenhouses }\end{array}$ & & & 75,000 \\
\hline Total cost of existing RE systems & & & 138,000 \\
\hline $\begin{array}{l}\text { Total cost of all the RE systems used } \\
\text { to cover all the energy needs in the } \\
\text { community including an additional } \\
\text { PV system. }\end{array}$ & & & 195,120 \\
\hline
\end{tabular}

almost double the cost of the systems used in the buildings. Additionally the cost of the required PVs was slightly higher than the cost of the solid biomass burn- 
ing systems. The installation cost of the existing RE systems in the community was $0.16 €$ per $\mathrm{kWh}$ of total thermal and electric energy delivered annually. In the case of an additional installation of a PV system to cover all the electricity needs in the community the total installation cost of RET would be $0.21 €$ per $\mathrm{kWh}$ of total energy delivered (due to the fact that solar-PV technology is more expensive than solid biomass burning technology). The annual cost of the solid biomass utilization has also been estimated in Table 7.

Therefore the cost of biomass used in the greenhouses was approximately five times higher than the cost of biomass used in the buildings. The annual cost of solid biomass per kWth delivered annually was $0.033 € / \mathrm{kWth}$. RE systems were installed in the community without any governmental financial support or subsidies. However the Greek government currently offers subsidies through the EU structural funds for the installation of various RE systems in buildings in order to improve their energy behavior. Also it offers financial support in agricultural greenhouses regarding sustainable energy investments in them.

\subsection{Environmental Assessment}

Utilization of RE instead of fossil fuels in the energy community has many environmental benefits including the decrease in greenhouse gas emissions due to energy use. In order to estimate the decrease in $\mathrm{CO}_{2}$ emissions, it has been assumed that the energy requirements in the community which are covered with $\mathrm{RE}$ were covered initially with grid electricity generated with fossil fuels as well as heating oil. The resulting $\mathrm{CO}_{2}$ emissions are presented in Table 8.

Table 7. Annual cost of the solid biomass used in the community.

\begin{tabular}{cccc}
\hline Biomass source & $\begin{array}{c}\text { Quantity annually } \\
\text { used (tons) }\end{array}$ & $\begin{array}{c}\text { Unit cost } \\
(€ / \text { ton })\end{array}$ & $\begin{array}{c}\text { Annual cost } \\
(€ / \text { year })\end{array}$ \\
\hline Olive tree wood & 35.22 & 150 & 5283 \\
Olive kernel wood & 200 & 120 & 24,000 \\
Total & 235.22 & & 29,283 \\
\hline
\end{tabular}

Table 8. Carbon emissions in the local energy community in the case where all its energy needs, which are now covered with renewable energies, were covered initially by fossil fuels.

\begin{tabular}{cccc}
\hline Energy use & $\begin{array}{c}\text { Quantity } \\
(\mathrm{kWh} / \text { year })\end{array}$ & $\begin{array}{c}\text { Unit emissions } \\
\left(\mathrm{kg} \mathrm{CO}_{2} \text { per } \mathrm{kWh}\right)\end{array}$ & $\begin{array}{c}\text { Annual emissions } \\
\left(\mathrm{kg} \mathrm{CO}_{2}\right)\end{array}$ \\
\hline Electricity & 36,000 & 0.75 & 27,000 \\
Heat & 821,877 & 0.306 & 251,494 \\
Total & 857,877 & & 278,494 \\
$\begin{array}{c}\text { Additional electricity used } \\
\text { in the community which } \\
\text { could be covered with solar } \\
\text { electricity in the future }\end{array}$ & 50,342 & 0.75 & 37,756 \\
Total & & & 316,250 \\
\hline
\end{tabular}


According to Table 8 the majority of $\mathrm{CO}_{2}$ emissions which are avoided in the energy community, because of the use of RE, were due to the heating energy use which is significantly higher than the electricity use. The capital cost of the required above-mentioned renewable energy systems in order to decrease $\mathrm{CO}_{2}$ emissions in the community was $0.50 €$ per $\mathrm{kg}$ of $\mathrm{CO}_{2}$ saved annually. In the case of an additional installation of a PV system to cover all the electricity needs in the community and to zero its $\mathrm{CO}_{2}$ emissions the total installation cost of all RET would be $0.62 €$ per $\mathrm{kg}$ of $\mathrm{CO}_{2}$ saved annually.

\section{Discussion}

Emphasis in the above-mentioned energy community has been given in energy supply of heat and electricity obtained with RE and the use of small-scale technologies. The high energy demand for space heating in the residential buildings is attributed to the fact that the majority of old buildings (Built before 2010) in Crete are poorly thermally insulated. Due to this fact their energy consumption is high compared with similar buildings in other EU countries with colder climate. The agricultural greenhouse is also poorly thermally insulated and its heat consumption could be decreased with better thermal insulation. Energy efficiency has not been addressed in the current work. However energy consumption for space heating, both in the buildings and in the greenhouse, could be decreased with the use of mature, reliable and well proven heat saving technologies. The bottom-up approach and the small-scale technologies used facilitated the acceptance of the energy technologies by the local community. Solar energy and solid biomass are abundant in Crete and the technologies used are mature, reliable and cost-effective. The existing net-metering initiative allowed the use of solar photovoltaics for covering almost all the energy needs in the grid-connected buildings. The main driver for the realization of the abovementioned energy community was economic due to: 1) existing financial incentives supporting the use of solar-PVs in buildings, and 2) the significant economic gains, particularly the last years, related with the use of olive kernel wood in the greenhouse instead of heating oil. Additional solar-PV installations in the future could cover all the electricity needs in the community including electricity consumption in the greenhouses. Technical maturity and economic viability of the RET used resulted in increased energy autonomy of the local community combined with the achievement of nearly zero- $\mathrm{CO}_{2}$ emissions due to energy use. Although the participating entities in the community are private bodies, future involvement of public organizations for the expansion of the energy community including the local municipality are desirable. The management of the energy community was evolved gradually starting from the design of the energy systems, with the support of external experts, followed with future planning for further development. Future orientation in the community should focus on the demand-side management reducing the energy consumption by the users and the use of additional environmentally-friendly technologies, including high-efficiency heat pumps. 
Since the renewable energy systems are continuously evolving, the realization of the energy community would have short and long term benefits in the local society, both economic and environmental. The comprehension of those benefits from the local society will trigger further development of renewable energy sources in various applications both in the private and the public sector.

\section{Conclusion}

A small renewable energy community located in Crete, Greece has been described and assessed. The community, privately owned, involved residential and agricultural activities. Small decentralized renewable energy systems were installed using a bottom-up approach and the commitment of the owners. Solar energy and solid biomass were used for covering its heat and electricity requirements. Installed RET included solar thermal, solar-PV and solid biomass burning utilizing local biomass sources. These technologies are reliable, mature and cost-effective. More than $90 \%$ of the current energy requirements in the community were covered with the installed RE systems and the rest could be covered in the future with a new PV system with nominal power of $33.6 \mathrm{kWp}$. The power of the installed solar-PV systems was $24 \mathrm{kWp}$ and the thermal power of the solid biomass burning systems was $1011 \mathrm{kWth}$. Total annual heat and power generation was $857,877 \mathrm{kWh}$ resulting in an annual reduction of $\mathrm{CO}_{2}$ emissions of 278,494 tons due to energy use. The cost of the installed RE systems was $0.16 €$ per total annual generated $\mathrm{kWh}$ and $0.50 €$ per $\mathrm{kg}$ of $\mathrm{CO}_{2}$ saved annually. Operation of the above-mentioned small renewable energy community in Crete had many energy, environmental, social and economic benefits. It increased its energy autonomy and decreased its dependence on fossil fuels. This indicated that it could be replicated in other territories, with similar RE availability, in order to increase their sustainability. It could also be disseminated and promoted as a good example of a local renewable energy community supported by new governmental policies. Future work should be focused on the growth of this energy community, exploiting the experience gained, and extended in more local activities involving the public sector and the municipal authorities.

\section{References}

[1] Sustainable Energy Authority of Ireland, Guidelines for a Sustainable Energy Community. https://www.seai.ie/SEC/Historical-Sustainable-Energy-Zones/Toolkit/Guidelines_f or_a_Sustainable_Energy_Community.pdf

[2] Walker, G. and Devine-Wright, P. (2008) Community Renewable Energy: What Should It Mean? Energy Policy, 36, 497-500. https://doi.org/10.1016/j.enpol.2007.10.019

[3] Rae, C. and Bradley, F. (2012) Energy Autonomy in Sustainable Communities-A Review of Key Issues. Renewable and Sustainable Energy Reviews, 16, 6497-6506. https://doi.org/10.1016/j.rser.2012.08.002

[4] Moloney, S., Horne, R.E. and Fien, J. (2010) Transitioning to Low Carbon Com- 
munities-From Behaviour Change to Systemic Change: Lessons from Australia. Energy Policy, 38, 7614-7623. https://doi.org/10.1016/j.enpol.2009.06.058

[5] Carlisle, N., Elling, J. and Penney, T. (2008) A Renewable Energy Community: Key Elements, U.S. Department of Energy, Technical Report NREL/TP-540-42774.

https://www.nrel.gov/tech_deployment/pdfs/re_community.pdf https://doi.org/10.2172/922880

[6] Wüstenhagen, R., Wolsink, M. and Bürer, M.J. (2007) Social Acceptance of Renewable Energy Innovation: An Introduction to the Concept. Energy Policy, 35, 2683 2691. https://doi.org/10.1016/j.enpol.2006.12.001

[7] Rogers, J.C., Simmons, E.A., Convery, I. and Weatherall, A. (2008) Public Perceptions of Opportunities for Community-Based Renewable Energy Projects. Energy Policy, 36, 4217-4226. https://doi.org/10.1016/j.enpol.2008.07.028

[8] Sustainable Energy Communities Framework (2016).

https://www.seai.ie/Grants/Better_Energy_Communities/SEC-Programme-overvie w.pdf

[9] Delrio, P. and Burguillo, M. (2008) Assessing the Impact of Renewable Energy Deployment on Local Sustainability: Towards a Theoretical Framework. Renewable and Sustainable Energy Reviews, 12, 1325-1344.

https://doi.org/10.1016/j.rser.2007.03.004

[10] Hielscher, S., Seyfang, G. and Smith, A. (2011) Community Innovation for Sustainable Energy. CSERGE Working Paper, No. 2011-03. http://hdl.handle.net/10419/48797

[11] Walker, G. and Cass, N. (2007) Carbon Reduction, "the Public" and Renewable Energy: Engaging with Socio-Technical Configurations. Area, 39, 458-469. https://doi.org/10.1111/j.1475-4762.2007.00772.x

[12] Walker, G. (2008) What Are the Barriers and Incentives for Community-Owned Means of Energy Production and Use? Energy Policy, 36, 4401-4405.

[13] Dusonchet, L. and Telaretti, E. (2010) Economic Analysis of Different Supporting Policies for the Production of Electrical Energy by Solar Photovoltaics in Western European Union Countries. Energy Policy, 38, 3297-3308.

[14] Luthander, R., Widén, J., Nilsson, D. and Palm, J. (2015) Photovoltaic Self-Consumption in Buildings: A Review. Applied Energy, 142, 80-94.

[15] Oliver, M. and Jackson, T. (2001) Energy and Economic Evaluation of Building-Integrated Photovoltaics. Energy, 26, 431-439.

[16] Hammond, G.P., Harajli, H.A., Jones, C.I. and Winnett, A.B. (2012) Whole Systems Appraisal of a UK Building Integrated Photovoltaic (BIPV) System: Energy, Environmental, and Economic Evaluations. Energy Policy, 40, 219-230.

[17] Vourdoubas, J. (2016) Creation of Zero $\mathrm{CO}_{2}$ Emissions Residential Buildings Due to Energy Use: A Case Study in Crete, Greece. Journal of Civil Engineering and Architecture Research, 3, 1251-1259.

[18] Tselepis, St. (2015) The PV Market Developments in Greece, Net-Metering Study Cases.

http://www.cres.gr/kape/publications/photovol/new/S\%20\%20Tselepis\%20\%20The \%20PV\%20Market\%20Developments\%20in\%20Greece\%20\%20Net-Metering\%20St udy\%20Cases\%2031st\%20EUPVSEC\%202015\%20Hamburg\%20\%207DV.4.26.pdf

[19] European Solar Thermal Industry Federation (2015) Solar Thermal Markets in Europe.

http://www.estif.org/fileadmin/estif/content/market_data/downloads/2014_solar_th ermal_markets_LR.pdf 
[20] European Solar Thermal Technology Platform, Solar Heating and Cooling for a Sustainable Energy Future in Europe.

http://www.estif.org/fileadmin/estif/content/projects/downloads/ESTTP_SRA_Revi sedVersion.pdf

[21] Technology Brief on Solar Heating and Cooling for Residential Applications, IEA-ETSAP and IRENA, January 2015.

http://www.irena.org/DocumentDownloads/Publications/IRENA_ETSAP_Tech_Br ief_R12_Solar_Thermal_Residential_2015.pdf

[22] Zografakis, N. (2005) Crete: A Preferential Island for Extensive Applications of Renewable Energy Sources in Europe and Mediterranean. Presentation in RE-Islands Conference, Brussels, 21st September 2005.

[23] Rösch, C. and Kaltschmitt, M. (1999) Energy from Biomass-Do Non-Technical Barriers Prevent an Increased Use? Biomass and Bioenergy, 16, 347-356.

[24] Scarlat, N., Dallemand, J.-F., Skjelhaugen, O.J., Asplund, D. and Nesheim, L. (2011) An Overview of the Biomass Resource Potential of Norway for Bioenergy Use. Renewable and Sustainable Energy Reviews, 15, 3388-3398.

[25] Vourdoubas, J. (2015) Overview of Heating Greenhouses with Renewable Energy Sources a Case Study in Crete-Greece. Journal of Agriculture and Environmental Sciences, 4, 70-76. https://doi.org/10.15640/jaes.v4n1a9

Submit or recommend next manuscript to SCIRP and we will provide best service for you:

Accepting pre-submission inquiries through Email, Facebook, LinkedIn, Twitter, etc. A wide selection of journals (inclusive of 9 subjects, more than 200 journals)

Providing 24-hour high-quality service

User-friendly online submission system

Fair and swift peer-review system

Efficient typesetting and proofreading procedure

Display of the result of downloads and visits, as well as the number of cited articles

Maximum dissemination of your research work

Submit your manuscript at: http://papersubmission.scirp.org/

Or contact ojee@scirp.org 